\title{
The Effectiveness of Reading English Learning Process Based on Blended Learning through "Absyak" Website Media in Higher Education
}

\author{
Abd. Syakur ${ }^{1}$, Zainal Fanani ${ }^{2}$, Rulam Ahmadi ${ }^{3}$ \\ ${ }^{1}$ Postgraduate Program of English Education, STKIP PGRI Sidoarjo, Indonesia \\ ${ }^{2}$ Doctoral Environmental Assessments and Development, Universitas Brawijaya, Indonesia \\ ${ }^{3}$ Postgraduate Program English Education, Universitas Islam Malang, Indonesia \\ syakurabdmpd@gmail.com
}

\begin{abstract}
The fastest development of technology and the internet in the 4.0 revolution era that influenced the world of education, especially higher education. Currently education focuses on outcome-based education, thus forcing all lecturers to innovate in teaching and learning. One form is by on-line learning for English learning materials developed through the website. This study analyzes the effectiveness of on-line based learning on websites on the ability to read students in the process of learning English at Universitas Brawijaya through "absyak" media websites. The use of the blended learning model has been done in several subjects, but for English subjects (reading) has never been done before. This research is quantitative descriptive. The research sample used a sample of 65 students through a questionnaire on students of the English language study program at Brawijaya University in academic year 2018/2019. The results showed that $81.99 \%$ agreed with the application of English reading learning based on blended learning through "absyak" media websites and the remaining $18.01 \%$ did not agree on learning English reading based on blended learning through "absyak" media websites. The implementation of online-based learning through "absyak" learning in the media can be effectively contained in high student responses, increased student scores and student attitudes towards variation and learning innovation.
\end{abstract}

Keywords

blended learning, learning process, reading English; media website

\section{Introduction}

The development of information and communication technology in the Industrial 4.0 era has had a great influence on the teaching and learning process in the world of education, especially in higher education and universities. Information technology can be accepted as a medium in conducting the educational process, including helping the teaching and learning process, which also involves searching for references and sources of information (Shahroom and Hussin, 2018).

In the industrial era 4.0, digital technology can have a negative impact on education if its use is not appropriate. Therefore, understanding the principles and factors that influence the effectiveness of digital technology in learning is something that is very important for an educator (Budiarta and Krismayani, 2014, Antony et al., 2015). An educator is required to have four competencies in order to use digital technology appropriately (Agussani and Ansari, 2020). First, an educator must understand and be able to use digital technology and its application. Second, have leadership competencies that are 
able to direct students to have an understanding of technology. Third, have the ability to predict precisely the direction of the turmoil of change and strategic steps to deal with it. Fourth, have competence in controlling themselves from all the turmoil of change, and be able to deal with it by bringing up ideas, innovation, and creativity (Shahroom and Hussin, 2018).

In accordance with the rules of the Government of the Republic of Indonesia, encourage the development of technology-based education information systems and information to provide access to learning resources for educators, education staff and students (Government Regulation No. 17 of 2010, articles 48 and 59). One learning media that uses information technology is known as e-learning.

The Industrial Revolution 4.0 is an opportunity for English lecturers to be creative in developing students' speaking skills (Agussani and Ansari, 2020). Lecturers can integrate face-to-face teaching with computer and network mediated activities, now known as "Blended learning" (Tayebinik and Puteh, 2013, Sulam et al., 2019).

The blended learning model which is a development of e-learning, is currently popular among lecturers namely EFL / ESL which is believed to be useful for creating a new and dynamic atmosphere while learning to read English according to the target (Wats and Wats, 2009, Khatib et al., 2011). Through the use of blended-learning, students can be given instructions, practice sending explanations about learning to read their English, receive feedback from peers and instructors on the outline of explanations about learning to read their English and sending explanations that hopefully can develop their verbal abilities and motivation in EFL classes (Ma et al., 2015, Hermann et al., 2016). This model offers lecturers a combination of face-to-face instruction with computer and network mediated instruction or on-line learning (Benito-Osorio et al., 2013). This is in accordance with the opinion (Henard and Roseveare, 2012) that learning with a blended learning strategy creates a pleasant new atmosphere and students are more independent in doing their tasks when following learning using bended learning.

One of the blended learning based learning is to use "absyak" media websites. "Absyak" media websites are used as variations or combined with face-to-face learning. "Absyak" media website is a portal that presents information in an interesting and motivating way which in turn becomes a controlled environment suitable for peer guidance in accordance with Permenristekdikti about the implementation of the Distance Learning Process (Yuliana, 2013, Soliman, 2014, Sulam et al., 2019).

The lecture process so far has only been defined as a process of learning through faceto-face in class. In fact, through a media that allows learning without face to face, the lecture process can still take place and learning interactions between lecturers and students can still be carried out (Antony et al., 2015). Media that can be used to overcome this is media learning "absyak" based on media websites that are used as variations in the application of blended learning.

In Brawijaya University and English language study program, the use of blended learning models has been carried out in several subjects. Then on this basis the researchers apply learning to read English based on blended learning (Tayebinik and Puteh, 2013). The use of media-based "absyak" learning in semester VII students of English language education programs at the Brawijaya University as part of the renewal and variation of learning models. As a research effort to see the impact, laws, the benefits of "absyak" learning based on media websites for students, researchers took the initiative to conduct research as a way to obtain information on student responses to English reading learning based on blended learning based on "absyak" learning based on media websites. The results of this study will serve as a basis 
for researchers and other lecturers to make further decisions on whether to use "absyak" learning based on media websites or not to apply blended learning in learning to read English.

\section{Review of Literature}

\subsection{English Learning Process}

In the process of learning and teaching English, speaking ability is the most important skill because this skill is the basis for verbal communication (Wats and Wats, 2009). Verbal communication refers to the ability to communicate verbally and accurately in the target language (Henard and Roseveare, 2012). Someone with a high level of oral proficiency can apply linguistic knowledge to new situations or contexts (Páez and Rinaldi, 2006). In most learning English, especially in English as a second / foreign language (ESL / EFL), instructors are often faced with a daunting task, namely making students overcome their anxiety to speak in the target language (Songsiri, 2007, Khatib et al., 2011, Jöns and Hoyler, 2013). Three main factors that contribute to student anxiety are cultural factors, linguistic factors, and psychological or affective factors. Student anxiety is usually associated with feelings of anxiety, anxiety, doubt, and frustration. This feeling influences students in doing assignments in front of the class and makes communicative stress (Páez and Rinaldi, 2006). Students should be given the opportunity to practice because they mostly have problems in the production of target languages (Songsiri, 2007, Kurniawan and Syakur, 2017).

\subsection{Reading English}

Reading generally involves two skills namely decoding and understanding (Songsiri, 2007, Sulam et al., 2019). Decoding is an isolable ability, which can be taught and assessed in a straightforward manner. While understanding is a complex skill that depends on variations in factors, context. Both the learning factor, the text factor, as well as teaching, all have a role. According to Brassell and Rasinski, reading refers to the ability to understand or create meaning from written texts (Ningsih et al., 2014). In the dictionary that reading words is the ability to test and understand the meaning of words in the text. So, reading is the process of a person in understanding a meaning in the text according to the level of ability possessed.

A different opinion is expressed by (O'Neill and Palmer, 2004) that reading is a complex process that requires analysis, coordination, and interpretation of various sources of information. Thus, it effectively raises the need for student literacy, especially for those who are willing to struggle, the need for learning to take on a number of complex activities (Manis et al., 2004). So, reading is the process for someone in analyzing and interpreting the meaning contained in the source of information or text (Henard and Roseveare, 2012, Budiarta and Krismayani, 2014). Thus, it can be understood that reading is a person's process of understanding the meaning of a text (Lindsey et al., 2003, Henard and Roseveare, 2012). In the process of reading requires a combination of complex activities such as understanding the meaning of vocabulary, phonemic, and sentences. Reading requires information support both visually and not. So, students in this action research learn to read well in order to understand the meaning of the text. The ability to read can be used for daily life both for the benefit of the educational process, work, and social life (Moussu and Llurda, 2008, Budiarta and Krismayani, 2014,Antony et al., 2015). 


\subsection{Blended-Learning}

Blended learning is a learning approach that combines strengths in face-to-face learning and e-learning. The idea of thinking about a blended learning environment is a learning environment where lecturers and students work with a combination of books, presentations and class activities, and digital resources including online material or mobile applications (Manis et al., 2004, Moussu and Llurda, 2008, Bashir and Thomas, 2020, Jeganathan and Fleming, 2020).

Blended learning as a combination of traditional learning characteristics and electronic learning environments (Hinneburg et al., 2020). Combining aspects of Blended learning (electronic format) such as web-based learning, video streaming, synchronous and asynchronous audio communication with traditional "face-to-face" learning (Budiarta and Krismayani, 2014, Bashir and Thomas, 2020). Blended learning is a learning process that combines independent online learning and face-to-face learning by utilizing media and technology (Hinneburg et al., 2020, Jeganathan and Fleming, 2020). This is an effort to provide more enjoyable and effective learning experiences for students (Kurniawan and Syakur, 2017, Jowsey et al., 2020). According to (Saiz-Manzanares et al., 2020) said blended learning is every time students can learn, because learning blended learning is partly learning face to face and partly with the help of the internet (Soliman, 2014, Mirmoghtadaie et al., 2020). Blended learning is a knowledge transfer program that utilizes more than one method to provide information to students (Hamid, 2019). Scientific knowledge is a type of knowledge that is obtained and accounted for scientifically or by applying scientific methods. While the scientific method is a procedure or systematic steps that need to be taken in order to obtain knowledge based on sensory perception and involves testing hypotheses and theories in a controlled manner. Scientific knowledge does not automatically appear when we observe the environment around us (Sitepu, 2019).

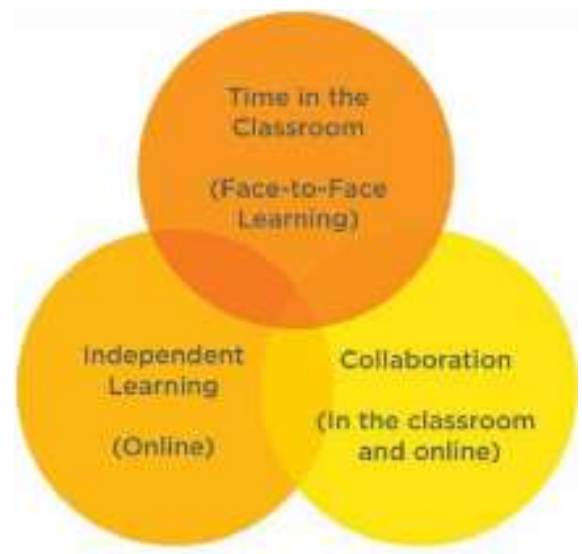

Figure 1. Blended Learning Concept

(Source: http://orangecharterschool.org/the-future-of-learning-has-arrived-at-ocs/)

\section{4 "Absyak" based on media websites}

Absyak is a validated media and has its validity in innovating a website-based learning media. This media has been designed to publish information by a writer and teacher. The learning process from the beginning to the end of the learning process until obtaining the final value which leads to reporting in PDDIKTI. For some people the website is used for the sake of the learning process, because of the ease of accessing information without having an account. According to (Benito-Osorio et al., 2013) the website has become a fun tool for some people to complete work and academic needs, as in universities lecturers have used the website for learning media. 


\section{Research Methods}

This research is a quantitative descriptive study with data collection techniques using on-line questionnaire. Descriptive research is research describing things that currently apply, whereas according to the type of data and how to process the numbers and analyzed using statistical tests, it is classified in quantitative research. The scores obtained were then analyzed using descriptive statistical techniques.

This research began in February to July 2019 in the English language education program at the University of Brawijaya. The variable of this research is the students' response to learning to read English based on blended learning through "absyak" learning based on media websites.

The response of students intended in this study was to agree or disagree with students in implementing learning to read English through learning "absyak" based on media websites. The population of this research is the students of English Language Study Program Universitas Brawijaya who are still actively taking English courses in the Academic year $2018 / 2019$ amounting to 65 people. The sample of this study was taken by the total sampling method so that the number of samples is the total population of 65 students. Data collection uses a closed questionnaire instrument with a choice of agree or disagree that already exists on the dashboard of the media website.

\section{Discussion}

In the results of the discussion of this study that the data processing in this study was done by processing questionnaire data using statistical and quantitative descriptive techniques which were further interpreted. The item statements contained in the questionnaire to be discussed are as follows:

Table 1. Statement of Student Response to Learning to Read English Based on Blended Learning Through "absyak" learning based on Media Website

\begin{tabular}{|c|c|}
\hline No & Statement \\
\hline 1. & $\begin{array}{l}\text { I like learning to read English using online learning systems such as "absyak" } \\
\text { learning based on media websites rather than learning face to face with lecturers in } \\
\text { class }\end{array}$ \\
\hline 2. & $\begin{array}{l}\text { "Absyak" learning based on media websites is an interesting medium in learning to } \\
\text { read English. }\end{array}$ \\
\hline 3. & $\begin{array}{l}\text { "Absyak" learning based on media websites makes me responsible and disciplined } \\
\text { in collecting structured assignments }\end{array}$ \\
\hline 4. & $\begin{array}{l}\text { "Absyak" learning based on media websites gives me new experiences / nuances in } \\
\text { learning to read English. }\end{array}$ \\
\hline 5. & I can save time in working on and collecting assignments \\
\hline 6. & With "absyak" learning based on media websites. \\
\hline 7. & $\begin{array}{l}\text { "Absyak" learning based on media websites makes it easy for me to access } \\
\text { learning material. }\end{array}$ \\
\hline 8. & $\begin{array}{l}\text { I can improve my understanding of reading English through video, PPT, PDF and } \\
\text { Microsoft Word learning uploaded through "absyak" learning based on media } \\
\text { websites. }\end{array}$ \\
\hline
\end{tabular}


Data obtained from the questionnaire by counting the number and which has been distributed to 65 percentages. The results of the analysis are then analyzed students can be seen in the following table.

Table 2. Results of Analysis of Student Responses to Blended Learning Based English Learning Through "Absyak" Media Websites.

\begin{tabular}{ccc}
\hline & \multicolumn{2}{c}{ Student Response } \\
\cline { 2 - 3 } Statement & Agree (\%) & Not Agree (\%) \\
\hline 1 & 36,36 & 63,64 \\
2 & 97,73 & 2,27 \\
3 & 93,18 & 6,82 \\
4 & 95,45 & 4,55 \\
5 & 95,45 & 4,55 \\
6 & 86,36 & 13,64 \\
7 & 74,13 & 25,87 \\
8 & 77,27 & 22,73 \\
\hline Average & $\mathbf{8 1 , 9 9}$ & $\mathbf{1 8 , 3 8}$
\end{tabular}

Based on the table, information was obtained about the students 'responses to the 8 point statement instruments which showed the students' responses to learning to read English based on blended learning through "absyak" Media Website.

First, $36.36 \%$ of students agreed to learn English using online learning systems such as "absyak" learning based on Media Websites rather than face-to-face learning, while $63.64 \%$ of students said they disagreed.

Second, $97.73 \%$ of students agreed that "absyak" learning based on Website Media was an interesting medium in learning to read English and only $2.27 \%$ of students said they disagreed.

Third, 93.18\% of students agreed that "absyak" learning based on Media Website made students responsible and disciplined in learning to read English and only $6.82 \%$ of students disagreed.

Fourth, 95.45\% of students agreed that "absyak" learning based on Media Website gave students new experiences / nuances in learning to read English and only $4.55 \%$ of students disagreed.

Fifth, $95.45 \%$ of students stated that students could save time in working on and collecting "absyak" learning tasks based on the Media Website and only $4.55 \%$ of students said they disagreed.

Sixth, $86.36 \%$ of students said they agreed that "absyak" learning based on Media Website made it easier for students to access learning material and $13.64 \%$ of students said they did not agree.

Seventh, $74.13 \%$ of students said that they agreed that students could improve their reading comprehension in English through learning videos that were uploaded through media-based "absyak" learning while $25.87 \%$ stated they disagreed.

Eighth, $77.27 \%$ of students said that they agreed to collect monolog / doalog assignments in English by uploading videos on "absyak" learning based on Media Website rather than appearing directly in class during lectures face to face with the lecturer. 
Based on table 2 it can also be concluded that the response of students to learning English reading based on blended learning through "absyak" learning based on Media Website is positive. This can be seen from the results of the average response of students on 8 statements that reached $82 \%$ agreed on learning English based on blended learning through "absyak" learning based on Website Media.

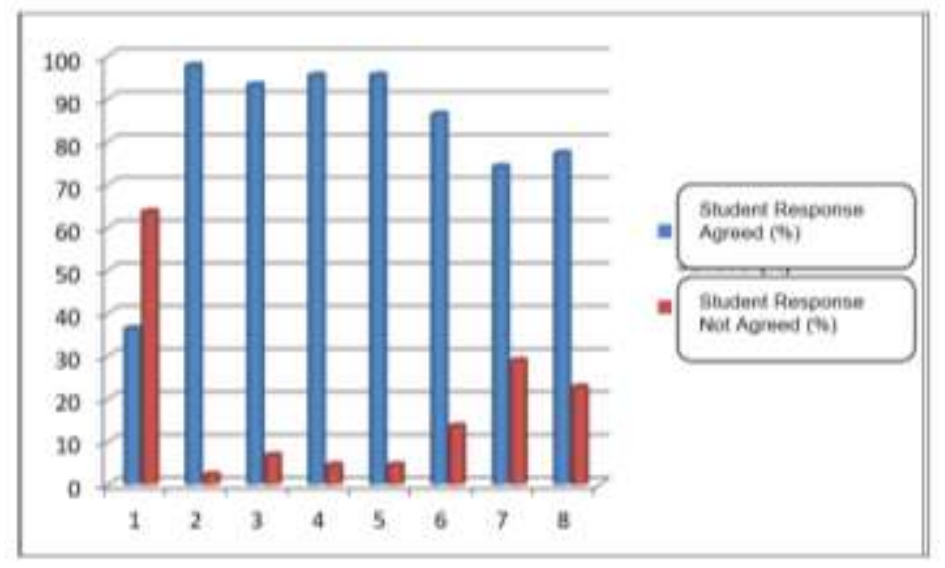

Figure 2. Student responses to Learning to read English

Based on Blended learning through "absyak" learning based on Website Media

The result of the research shows that the response of students to learning to read English based on blended learning can be seen in images 2 above. These results can also be called conventional learning, attractiveness, student character formation, learning innovation, time efficiency, ease of learning, speed of understanding, and assignment.

Comparison of aspects with conventional learning, students still tends to choose conventional learning. This is because the custom is given directly from the lecturer. So when they find new learning innovations, students tend to slow down to understand their use and use. Students also find it difficult to access "absyak" learning based on the Media Website because of limited quota or internet access. The attractiveness aspect, students are interested and happy in the interface or appearance that tends to be familiar with their daily life because it looks similar to the appearance of the PDDIKTI feeder and is combined with four media including Video Animation, PPT, Pdf and Microsoft word so students are free to choose according to their abilities.

Aspects of the formation of student character, the assignment facilities provided "absyak" learning based on Website Media help students to be more responsible and disciplined in collecting assignments because assignments have been arranged to be given time for assignments. If students are late in collecting assignments, they will be listed in the "absyak" learning system / account based on the lecturer Media Website. This encourages students to be disciplined and timely in working on and collecting assignments. Aspects of learning innovation, students obtain new learning models based on information and communication technology so that students do not stutter about technology and can be more creative in learning (Ortega-Moran et al., 2020)

The aspect of time efficiency makes it easy for students and lecturers for time constraints. Learning that cannot be done face-to-face can be replaced by virtual learning through media-based "absyak" learning that can be monitored directly by the lecturer and not limited by time. So that less meeting time can be overcome by working on assignments and gathering them through "absyak" learning based on Media Websites.

The aspect of ease of learning, students can learn independently by downloading files for other student assignments, including learning video material about monologues / 
dialogues in reading English. Students can see repeatedly, observe, study carefully compared to see directly.

In the assignment aspect, students tend to like assignments through media-based "absyak" learning rather than appearing directly in front of the class (Soliman, 2014). It also follows up on the difficulties of students who face nervousness when the monologue / dialogue is directly in front of the class.

The positive response of students to blended learning based on "absyak" learning based on Media Website on learning to read English shows acceptance of learning innovations with new technology in learning to read English. The results of this study can be the basis for researchers to organize innovative and creative learning, especially the development of blended learning based on "absyak" learning based on Media and other online websites.

\section{Conclusion}

The implementation of online based learning through "absyak" learning in the media can be concluded to be effective. The learning process provides a high agreed response to the implementation of the absyak media learning process. The learning process also has an impact on increasing the value obtained by students, giving an impact on the development of students' daily grades has also shown a significant increase. Thus, lecturers at Brawijaya University, especially English lecturers who will develop their knowledge can use, utilize or develop media-based blended learning in learning as variations and innovations in English language learning, so learning is not monotonous and can encourage student learning, and able to help with limited time and space.

\section{References}

Agussani, A. and K. Ansari. 2020. The Approach to Indonesian Language and Literature Curriculum in the Industrial Revolution Era 4.0 and Society 5.01. Kumpulan Penelitian dan Pengabdian Dosen.

Antony, J., W. K. Balzer, M. H. Brodke, and E. T. Kizhakethalackal. 2015. Lean higher education: successes, challenges, and realizing potential. International Journal of Quality \& Reliability Management.

Bashir, K. and S. Thomas. 2020. Educational Approach of Blended Learning in Teaching Benign Paroxysmal Positional Vertigo in an Emergency Department. J Coll Physicians Surg Pak 30(3):299-303.

Benito-Osorio, D., M. Peris-Ortiz, C. R. Armengot, and A. Colino. 2013. Web 5.0: the future of emotional competences in higher education. Global Business Perspectives 1(3):274287.

Budiarta, I. K. and N. W. Krismayani. 2014. Improving speaking skill and developing character of the students through collaboration of think-pair-share and the concept of tri kaya parisudha. Jurnal Santiaji Pendidikan (JSP) 4(2):73-80.

Henard, F. and D. Roseveare. 2012. Fostering quality teaching in higher education: Policies and practices. An IMHE Guide for Higher Education Institutions:7-11.

Hermann, M., T. Pentek, and B. Otto. 2016. Design principles for industrie 4.0 scenarios. Pages 3928-3937 in Proc. 2016 49th Hawaii international conference on system sciences (HICSS). IEEE.

Hinneburg, J., J. Luhnen, A. Steckelberg, and B. Berger-Hoger. 2020. A blended learning training programme for health information providers to enhance implementation of the 
Guideline Evidence-based Health Information: development and qualitative pilot study. BMC Med Educ 20(1):77.

Jeganathan, S. and P. S. Fleming. 2020. Blended learning as an adjunct to tutor-led seminars in undergraduate orthodontics: a randomised controlled trial. Br Dent J 228(5):371-375.

Jöns, H. and M. Hoyler. 2013. Global geographies of higher education: The perspective of world university rankings. Geoforum 46:45-59.

Jowsey, T., G. Foster, P. Cooper-Ioelu, and S. Jacobs. 2020. Blended learning via distance in pre-registration nursing education: A scoping review. Nurse Educ Pract 44:102775.

K. Hamid, A., et al. (2019). Evaluation of Implementation of Blanded Learning Implementation in Universitas Negeri Medan. Britain International of Linguistics, Arts and Education (BIoLAE) Journal, 224-231

Khatib, M., S. Rezaei, and A. Derakhshan. 2011. Literature in EFL/ESL Classroom. English Language Teaching 4(1):201-208.

Kurniawan, A. and A. Syakur. 2017. The Correlation of Emotional Intelligence and Spiritual of Intelligence to Effectiveness Principals of Leadership. International Journal of Psychological and Brain Sciences 2(1):1-9.

Lindsey, K. A., F. R. Manis, and C. E. Bailey. 2003. Prediction of first-grade reading in Spanish-speaking English-language learners. Journal of educational psychology 95(3):482.

Ma, J., S. Baum, M. Pender, and D. W. Bell. 2015. Trends in College Pricing, 2015. Trends in Higher Education Series. College Board.

Manis, F. R., K. A. Lindsey, and C. E. Bailey. 2004. Development of reading in grades K-2 in Spanish-speaking English-language learners. Learning Disabilities Research \& Practice 19(4):214-224.

Mirmoghtadaie, Z., N. Kohan, and D. Rasouli. 2020. Determination and Comparison of the Factors Related to Effective Blended Learning in Medical Sciences from the Viewpoints of Instructors and Learners. Adv Med Educ Pract 11:205-214.

Moussu, L. and E. Llurda. 2008. Non-native English-speaking English language teachers: History and research. Language teaching 41(3):315-348.

Ningsih, A., Y. Sabat, and A. Syakur. 2014. Comic Strips as Media to Develop Student's Writing Ability in Composing Recount Text for The Tenth Graders of SMA Muhammadiyah 2 Sidoarjo (Komik Strips Sebagai Media Untuk Mengembangakan Kemampuan Menulis Siswa Dalam Mengarang Teks Recount. English Education 2(2).

O’Neill, M. A. and A. Palmer. 2004. Importance-performance analysis: a useful tool for directing continuous quality improvement in higher education. Quality assurance in education.

Ortega-Moran, J. F., B. Pagador, J. Maestre-Antequera, A. Arco, F. Monteiro, and F. M. Sanchez-Margallo. 2020. Validation of the online theoretical module of a minimally invasive surgery blended learning course for nurses: A quantitative research study. Nurse Educ Today 89:104406.

Páez, M. and C. Rinaldi. 2006. Predicting English word reading skills for Spanish-speaking students in first grade. Topics in Language Disorders 26(4):338.

Saiz-Manzanares, M. C., M. C. Escolar-Llamazares, and A. Arnaiz Gonzalez. 2020. Effectiveness of Blended Learning in Nursing Education. Int J Environ Res Public Health 17(5).

Shahroom, A. A. and N. Hussin. 2018. Industrial revolution 4.0 and education. International Journal of Academic Research in Business and Social Sciences 8(9):314-319.

Sitepu, T. (2019). Cooperative Model in Language Reasoning: Indonesian Language Teaching Materials in Teacher Training and Education Faculty of Muhammadiyah 
Sumatera Utara University. Britain International of Linguistics, Arts and Education (BIoLAE) Journal, 51-59.

Soliman, N. A. 2014. Using e-learning to develop EFL students' language skills and activate their independent learning. Creative Education 2014.

Songsiri, M. 2007. An action research study of promoting students' confidence in speaking English. Victoria University.

Sulam, K., A. Syakur, and L. Musyarofah. 2019. The Implementation of 21St Century Skills As The New Learning Paradigm to The Result Of Student's Career And Life Skills. Magister Scientiae 2(46):228-237.

Tayebinik, M. and M. Puteh. 2013. Blended Learning or E-learning? Tayebinik, M., \& Puteh, M.(2012). Blended Learning or E-learning:103-110.

Wats, M. and R. K. Wats. 2009. Developing Soft Skills in Students. International Journal of Learning 15(12).

Yuliana, A. S., and A. Soegito. 2013. The application of audiolingual method to improve students speaking ability. JurnalPendidikanBahasaInggris STKIP PGRI Sidoarjo $1(1): 88-93$ 